\title{
PCR identification of Pseudomonas aeruginosa and direct detection in clinical samples from cystic fibrosis patients
}

\author{
LUIZ VICENTE FERREIRA DA SILVA FILHO, JOSÉ EDUARDO LEVI*, CHRISTINA NAOMI ODA \\ BENTO†, SONNIA REGINA TESTA DA SILVA RAMOS and TATIANA ROZOV \\ Instituto da Criança, Hospital das Clinicas, University of São Paulo Medical School (FMUSP), Av. Dr Enéas \\ Carvalho de Aguiar, 647 Cerqueira César, CEP 05403-900 São Paulo SP, * Laboratory of Virology, Instituto de \\ Medicina Tropical de São Paulo, FMUSP and †Microbiology Section of Central Laboratory, Hospital das \\ Clínicas, FMUSP, São Paulo, Brazil
}

This report describes a PCR primer pair that targets the algD GDP mannose gene of Pseudomonas aeruginosa and produces a specific 520-bp PCR product useful for $P$. aeruginosa identification. This PCR assay was tested with 182 isolates of $P$ aeruginosa and 20 isolates of other bacterial species, and demonstrated $100 \%$ specificity and sensitivity. The test was also able to detect $P$. aeruginosa directly in clinical samples such as sputum or throat swabs obtained from cystic fibrosis patients. The combination of this primer with a universal bacterial primer, acting as a control to assess DNA quality in the sample, resulted in a robust PCR method that can be used for rapid $P$. aeruginosa detection.

\section{Introduction}

Pseudomonas aeruginosa is a common cause of nosocomial infection and the most important pathogen for cystic fibrosis (CF) patients. It plays an important role in the pathogenesis of CF pulmonary disease, and once established in the airways of these patients is seldom eradicated $[1,2]$. Initial intermittent colonisation of the upper respiratory tract usually precedes chronic endobronchial colonisation with mucoid strains and this in turn is associated with progressive deterioration of lung function [3], the leading cause of death among these patients $[1,4]$.

Alginate production plays a central role in the pathogenesis of chronic pulmonary infection in CF patients, and almost all patients colonised with $P$. aeruginosa will acquire mucoid (alginate-producing) strains [4-6]. Alginate synthesis is regulated by several genes, but the $\operatorname{alg} D$ gene - which codes for GDP mannose dehydrogenase - seems to occupy a strategic position in the regulation of alginate synthesis, as this enzyme is the first enzyme specific for alginate production in the alginate biosynthetic pathway $[6,7]$.

Received 22 April 1998; revised version accepted 10 Aug. 1998.

Corresponding author: Dr L. V. F. da Silva Filho (e-mail: vicres@usp.br).
Once diagnosed, all patients with $\mathrm{CF}$ are periodically assessed for airway colonisation, and some CF centres recommend aggressive treatment after the first isolation of $P$. aeruginosa in an attempt to eradicate it $[8,9]$. Microbiological identification of the bacteria is usually easy to perform, but negative culture results can occur during antibiotic treatment or in patients with a small number of bacteria in the airways. Furthermore, the assessment of airway colonisation in children younger than 5 years old is less reliable, as they usually cannot produce sufficient amounts of sputum for microbiological analysis, and throat swabs must be collected instead.

This report describes a new specific primer pair targeting the $\operatorname{alg} D$ gene of $P$. aeruginosa, suitable for identification of the organism by PCR. This primer pair was also used along with a universal primer pair for bacteria [10], to assure DNA quality in samples negative for $P$. aeruginosa.

\section{Materials and methods}

\section{Bacterial strains}

A total of $182 P$. aeruginosa strains from different sources and geographic regions was employed in this study (Table 1); 20 strains of other bacterial species of medical importance which colonise CF patients were studied: Staphylococcus aureus, Streptococcus pneu- 
Table 1. Source and geographic location of strains of $P$. aeruginosa studied

\begin{tabular}{llc}
\hline Source & Geographic location & $\begin{array}{c}\text { Number of } \\
\text { isolates }\end{array}$ \\
\hline Respiratory tract* $^{*}$ & UBC/Vancouver, Canada & 19 \\
Sputum* $^{*}$ & ICr/São Paulo, Brazil & 76 \\
Throat swabs* $^{*}$ & ICr/São Paulo, Brazil & 11 \\
Hands $^{*}$ & ICr/São Paulo, Brazil & 5 \\
Undellaneous $^{\dagger \ddagger}$ & HIAE/São Paulo, Brazil & 68 \\
Total $^{\dagger}$ & Uberlândia, Brazil & 3 \\
\hline
\end{tabular}

UBC, University of British Columbia; ICr/HCFMUSP, Instituto da Criança, Hospital das Clínicas, University of São Paulo Medical School; HIAE/SP, Albert Einsten Hospital; Uberlândia/MG, Medical School of Uberlândia, Minas Gerais.

${ }^{*}$ Samples from CF patients.

${ }^{\dagger}$ Clinical samples, non-CF patients.

${ }^{\ddagger}$ Miscellaneous samples: tracheal aspirate, bronchoalveolar lavage fluid, surgical wound, urine, ocular secretion, venous catheter.

moniae, Haemophilus influenzae, Escherichia coli, Klebsiella pneumoniae, Acinetobacter calcoaceticus, Enterobacter aerogenes, P. stutzeri, Stenotrophomonas maltophilia and Burkholderia cepacia.

\section{Cultures and DNA extraction}

The bacteria were cultivated on a selective medium (Bacto Cetrimide Agar Base, Difco), identified by standard microbiological methods, and, when necessary, by complementary biochemical tests. Throat samples were first incubated in liquid thioglycollate medium (Difco) at $37^{\circ} \mathrm{C}$ for $24 \mathrm{~h}$. Bacteria were collected directly from the culture plate, washed twice in a solution of $10 \mathrm{mM}$ Tris $\mathrm{HCl}$ and $1 \mathrm{mM}$ EDTA, $\mathrm{pH}$ 8.0 (TE) and incubated in $50 \mathrm{mM}$ Tris, $\mathrm{pH} 8.0$, containing SDS $0.5 \%$ and proteinase $\mathrm{K}$ (Gibco-BRL) $200 \mu \mathrm{g} / \mathrm{ml}$ for $2 \mathrm{~h}$ at $65^{\circ} \mathrm{C}$. This was followed by two organic extractions with phenol and one with chloroform [11]. DNA was precipitated with cold ethanol, centrifuged, dried and resuspended in TE buffer, $\mathrm{pH}$ 8.0. The DNA concentration was then assessed at $260 \mathrm{~nm}$ in a spectrophotometer (Pharmacia, São Paulo, Brazil).

\section{Direct detection in clinical samples}

Direct detection of $P$. aeruginosa by PCR was tested on 15 clinical samples (sputum and throat swabs) from CF patients who attended the Pediatric Pulmonology Outpatient Clinic of Instituto da Criança, São Paulo. All the sputum specimens were divided into two portions and one of them was cultivated as described previously. Throat samples were collected by one of us (L.V.F.S.F.) using two swabs simultaneously, one was cultivated and the other was used for the PCR assay. Written informed consent was obtained from the parents for the collection of each specimen, in accordance with the ethical guidelines of the Institution.

\section{DNA extraction}

Clinical samples were processed as described by Campbell et al. [12]. Sputum samples were diluted in an equal volume of $100 \mathrm{mM}$ Tris, $90 \mathrm{mM}$ boric acid and $1 \mathrm{mM}$ EDTA, pH 8.0 (TBE). Throat swabs were soaked in $1 \mathrm{ml}$ of the same solution and shaken vigorously. The diluted samples were then frozen instantaneously in liquid nitrogen, boiled for $30 \mathrm{~min}$ and centrifuged at $13800 \mathrm{~g}$ for $5 \mathrm{~min}$. The supernatant fraction was separated and $5 \mu \mathrm{l}$ were used directly for the PCR reactions.

\section{Sensitivity assay}

Serial dilutions from $20 \mathrm{ng} / \mu \mathrm{l}$ to $2 \mathrm{fg} / \mu \mathrm{l}$ of $P$. aeruginosa DNA, obtained from cultures, were added to a clinical sample from a throat swab without $P$. aeruginosa, to estimate the sensitivity of the method for direct detection.

\section{Primer selection}

The $\operatorname{alg} D$ GDP mannose dehydrogenase gene of $P$. aeruginosa contains 2032 bp (GenBank, access no. 400337, identification no. g45267) and its expression results in a $48-\mathrm{kDa}$ protein, the enzyme GDP mannose dehydrogenase, the first enzyme that is specific for alginate production in the alginate biosynthetic pathway [7]. The promoter region of this gene is well known for its regulatory role in the transcription of other genes involved in alginate biosynthesis [6]. The selected primers VIC1 (5'TTCCCTCGCAGAGAAAACATC $3^{\prime}$ ) and VIC2 (5'CCTGGTTGATCAGGTCGATCT $3^{\prime}$ ) were designed to amplify a 520-bp segment of the $\operatorname{alg} D$ GDP mannose dehydrogenase gene of $P$. aeruginosa. Bacterial universal bacterial primers 11E-13B, targeting the $16 \mathrm{~S}$ RNA gene of bacteria [10] were also employed, to assure DNA quality.

\section{PCR conditions}

PCR was performed in a $25-\mu 1$ reaction mixture containing $150 \mathrm{ng}$ of DNA template or $5 \mu \mathrm{l}$ of the processed clinical samples, $0.4 \mu \mathrm{mol} / \mathrm{L}$ of each primer, $200 \mu \mathrm{mol} / \mathrm{L}$ each of the four nucleotide triphosphates, $2 \mathrm{mM} \mathrm{MgCl}_{2}, 50 \mathrm{mM} \mathrm{KCl}, 10 \mathrm{mM}$ Tris (pH 8.0) and $1 \mathrm{U}$ of Taq DNA polymerase (Pharmacia). Samples were subjected to the following thermocycling process (Perkin Elmer 2400): $94^{\circ} \mathrm{C}$ for $5 \mathrm{~min}$, followed by 30 cycles of $94^{\circ} \mathrm{C}$ for $1 \mathrm{~min}, 60^{\circ} \mathrm{C}$ for $1 \mathrm{~min}$ and $72^{\circ} \mathrm{C}$ for $1 \mathrm{~min}$. A final extension step at $72^{\circ} \mathrm{C}$ was continued for another $7 \mathrm{~min}$. A tube containing the reaction mixture and sterile water was included in all reactions as a negative control. 


\section{Results}

\section{Bacterial isolates}

A total of $182 P$. aeruginosa isolates from multiple sources was tested in the PCR protocol and a positive identification, characterised by the presence of a specific 520 -bp product, was obtained with 176 samples. The six samples that did not show the specific 520-bp product were isolated from $\mathrm{CF}$ patients at the Instituto da Criança, São Paulo, Brazil. These isolates were resubmitted for microbiological identification and were found to be $B$. pickettii (two isolates), $P$. mendocina (two), Alcaligenes xylodoxidans (one) and $P$. putida (one) (Fig. 1). As a control, concomitant re-identification of $12 P$. aeruginosa PCR-positive isolates resulted in confirmation of the bacterial identity of all specimens.

The specificity of PCR with the primer pair VIC1VIC2 was tested against a panel of strains of bacterial species which are of medical importance and known to colonise CF patients (Fig. 2). A 233-bp fragment, which is the expected result of amplification with the bacterial universal primers, confirmed successful DNA extraction, while a specific fragment of $520 \mathrm{bp}$ was seen only in the samples of $P$ aeruginosa DNA. The sensitivity of the method was also tested with $P$. aeruginosa DNA amounts ranging from $100 \mathrm{ng}$ to $100 \mathrm{fg}$ (results not shown). Adequate products were obtained with a minimum of $100 \mathrm{pg}$ of $P$. aeruginosa DNA, which corresponds to c. $8 \times 10^{3}$ bacteria [13].

\section{Clinical samples}

A total of 15 clinical samples was collected and tested by the PCR method, with concomitant culture as described above (Table 2). Positive PCR identification

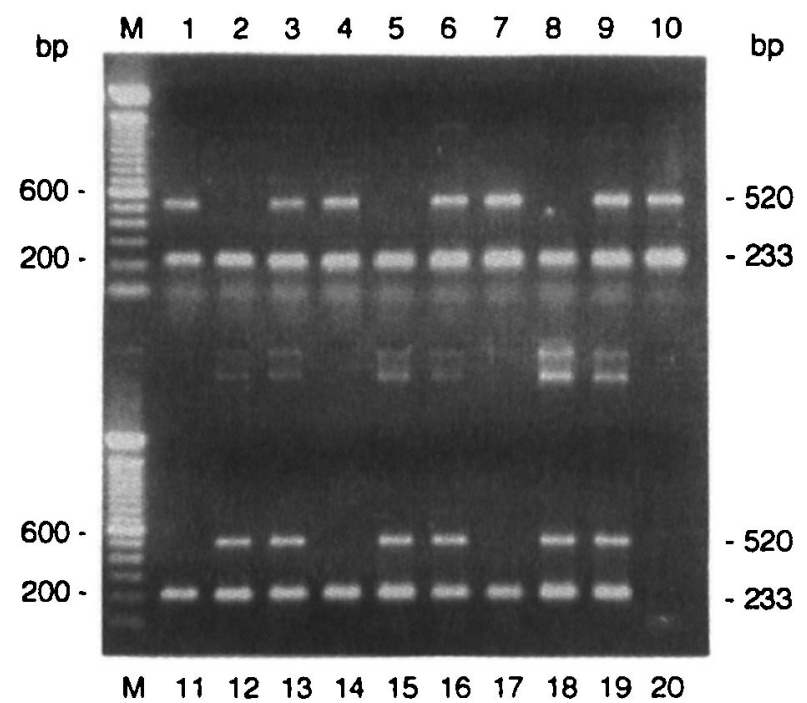

Fig. 1. Agarose gel electrophoresis of PCR products from isolates from CF patients at the Instituto da Criança, Brazil. Lanes: M, mol.wt marker (100-bp ladder, Pharmacia); 2, 11, P. mendocina; 5, 8, B. pickettii; 14, P. putida; 17, A. xylosoxidans; 20, negative control (DNA added); $P$. aeruginosa strains are shown in the remaining lanes.

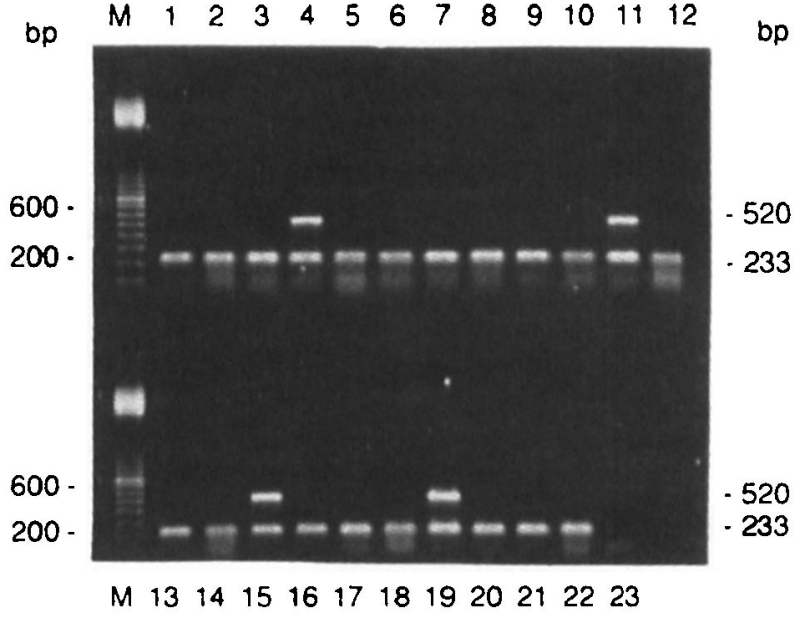

Fig. 2. Agarose gel electrophoresis of PCR products. Lanes: M, mol.wt marker (100-bp ladder, Pharmacia); 4, 11, 15, 19, $P$. aeruginosa strains; 1, 16, S. maltophilia; 2, 10, Strep pneumoniae; 3, 17, Acinetobacter calcoaceticus; 5, 18, B. cepacia; 6, Staph. aureus; 7, 22, Ent. aerogenes; 8, 14, H. influenzae; 9, 13, 21, E. coli; 12, $P$. stutzeri; 20, $K$. pneumoniae; 23, negative control (no DNA added).

of $P$ aeruginosa was obtained in seven samples, all but one positive by culture (Fig. 3). One sample positive by culture for $P$. aeruginosa gave a negative PCR test; this sample did not show the 233-bp product, corresponding to the amplification of bacterial ribosomal DNA. With this exception, all the other 14 samples tested produced the amplification product for bacterial ribosomal DNA. One of the $P$. aeruginosa culture-negative samples yielded a 520-bp product in the PCR reaction. This sample was collected from a CF patient with chronic colonisation by $P$. aeruginosa whose subsequent culture (2 weeks later) grew $P$. aeruginosa. Other microorganisms identified in cultures were Staph. epidermidis, E. coli, Pseudomonas sp., Staph. aureus, $H$. influenzae, Aspergillus sp. and Candida sp.

Frequently, sputum samples produced smears on the agarose gel that were attributed to an excess of DNA. In these instances, the samples were diluted in sterile water and repeat of the PCR resulted in proper amplification and product visualisation.

\section{Discussion}

The sequence of the $\operatorname{alg} D$ GDP mannose gene described by Deretic et al. [7] was chosen as the target for the PCR protocol because of its importance to the $P$. aeruginosa species. It codes for a pivotal enzyme of the alginate biosynthetic pathway and this polymer represents an important protective mechanism for the bacteria. McIntosh et al. [14] have described a PCR protocol focused on this gene, targeting a locus $c$. $500 \mathrm{bp}$ distant from the promoter region. They demonstrated its specificity as a target for PCR identification of $P$. aeruginosa in a study of a small but representa- 
Table 2. Culture and PCR results for clinical samples from CF patients of Instituto da Criança, São Paulo, Brazil, with the respective lanes on the agarose $1.5 \%$ gel shown in Fig. 3

\begin{tabular}{lclccc}
\hline & & & \multicolumn{2}{c}{ P. aeruginosa } & \\
\cline { 3 - 4 } Patient & Lane no. & Sample & Culture & PCR & Ribosomal DNA \\
\hline A & 3 & Sputum & - & - & + \\
B & 4 & Sputum & + & + & + \\
C & 5 & Sputum & - & + & + \\
D & 6 & Sputum & - & - & + \\
E & 7 & Sputum & - & - & + \\
F & 8 & Sputum & + & + & + \\
G & 9 & Sputum & + & + & + \\
H & 10 & Sputum & + & - & - \\
I & 11 & Sputum & - & - & + \\
J & 12 & Sputum & + & + & + \\
K & 13 & Throat swab & - & - & + \\
L & 14 & Throat swab & - & - & + \\
M & 15 & Throat swab & + & + & + \\
N & 16 & Throat swab & - & - & + \\
O & 17 & Throat swab & + & + & + \\
Total & & & 7 & 7 & + \\
\hline
\end{tabular}

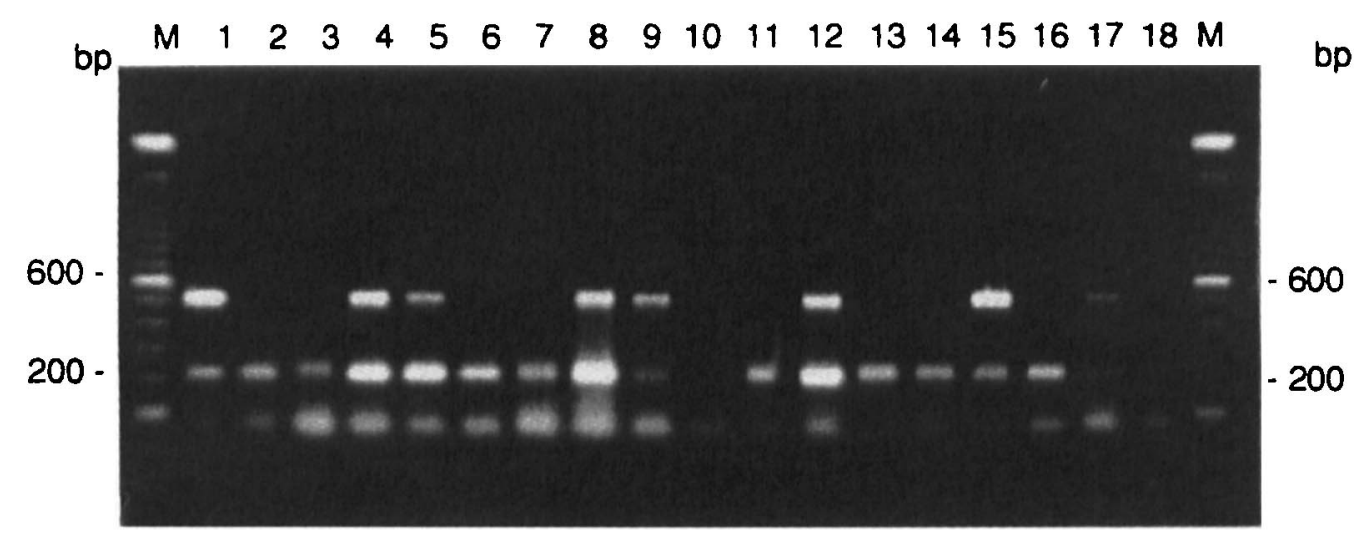

Fig. 3. Agarose gel electrophoresis of PCR products from clinical samples. Lanes: M, mol. wt marker (100-bp ladder); 1, $P$. aeruginosa strain from São Paulo, Brazil; 2, S. maltophilia strain; 3-12, sputum samples; 13-17, throat swab samples; 18, negative control (no DNA added); 1, $P$ aeruginosa, positive control; 4, 5, 8, 9, 12, 15, 17, $P$. aeruginosapositive samples; 10, represents a sputum sample that did not result in PCR products (see Table 2).

tive number of $P$ aeruginosa strains, and furthermore tested a large number of species belonging to group I of the Pseudomonas genus. They showed a high sensitivity in terms of quantity of DNA and colony forming units (cfu) when applying the nested PCR method, but this procedure intensifies the risk of contamination due to carry over of DNA. This is a potential problem for a diagnostic method that may lead to clinical intervention such as aggressive antibiotic therapy.

O'Callaghan et al. [15] also described a PCR assay for $P$. aeruginosa and $B$. cepacia identification which used 16S RNA sequence amplification followed by hybridisation with specific oligonucleotide probes. This method proved to be highly reproducible and sensitive, and was also applied to direct detection in sputum samples. Campbell et al. [12] have also focused on specific 16S RNA PCR for $B$. cepacia identification. In a recent publication, De Vos and coworkers [16] described a multiplex-PCR protocol targeting the outer-membrane lipoprotein genes oprI and $o p r L$, which was able to identify $P$. aeruginosa and other fluorescent Pseudomonas strains, and was also suitable for direct detection in sputum and skin biopsy samples.

In the present study, a similar approach of developing a PCR methodology for $P$. aeruginosa identification was used, with the $\operatorname{alg} D$ GDP mannose dehydrogenase gene as the target. A large number of strains from different sources and geographical locations was tested and a sensitive and specific method for $P$. aeruginosa identification was obtained. The direct detection of $P$. aeruginosa in clinical samples was also attempted, including samples from throat swabs, as this is the source of material commonly used to assess bacterial colonisation in young CF patients. The method used for sample processing [12] was chosen because of its simplicity, but further studies on the use of substances such as phenol or guanidine thiocyanate in the DNA extraction step may provide higher sensitivity, because this may eliminate inhibitory agents present in some clinical samples. 
The assay has been standardised and can be used directly on clinical samples, with the advantage of the concurrent use of a set of universal bacterial primers to assure DNA quality in $P$. aeruginosa PCR-negative samples. The study of respiratory samples allowed the use of this kind of control, as these samples will always contain some bacterial DNA from the normal flora. Interestingly, some of the patients submitted to sample collection (B, C, D and H) were on aerosolised dornase alpha (Pulmozyme ${ }^{\circledR}$ ) therapy [17], but this apparently did not influence the results, except for one sample $(\mathrm{H})$ that did not yield any PCR product.

Further studies with a large number of clinical samples and quantitative bacterial cultures are necessary to determine the real usefulness of this method in the clinical management of these patients. The possibility of simultaneous detection of other bacteria such as Staph. aureus and B. cepacia is another aspect to be studied further, and would represent a major advance in CF patient care. In conclusion, a simple, specific and sensitive method has been developed for identification of $P$. aeruginosa that can be applied directly to clinical samples, and its execution requires $<6 \mathrm{~h}$ from sample preparation to final result.

We thank Dr Otávia Luisa Silva Damas de Caballero (Ludwig Institute for Cancer Research, São Paulo branch) for helpful advice, and Dr David P. Speert and his team for providing bacterial samples and constant support. We also thank Dr Cláudio Sérgio Pannuti and colleagues at the Laboratory of Virology (Instituto de Medicina Tropical de São Paulo) for technical assistance and for encouraging and supporting this work. This study was supported by Fundação de Amparo à Pesquisa do Estado de São Paulo (FAPESP), grant no. 1995/00033-6. L.V.F.S.F. is sponsored by CAPES, Brazil.

\section{References}

1. Wood RE, Boat TF, Doershuk CF. State of the art: cystic fibrosis. Am Rev Respir Dis 1976; 113: 833-878.

2. Høiby N. Microbiology of lung infections in cystic fibrosis patients. Acta Paediatr Scand 1982; Suppl 301: 33-54.

3. Pedersen SS, Høiby N, Espersen F, Koch C. Role of alginate in infection with mucoid Pseudomonas aeruginosa in cystic fibrosis. Thorax 1992; 47: 6-13.

4. Zach MS. Lung disease in cystic fibrosis - an updated concept. Pediatr Pulmonol 1990; 8: 188-202.

5. Pedersen SS. Lung infection with alginate-producing, mucoid Pseudomonas aeruginosa in cystic fibrosis. Chapter 3: The parasite. APMIS 1992; 100 Suppl 28: 21-26.

6. Govan JRW, Deretic V. Microbial pathogenesis in cystic fibrosis: mucoid Pseudomonas aeruginosa and Burkholderia cepacia. Microbiol Rev 1996; 60: 539-574.

7. Deretic V, Gill JF, Chakrabarty AM. Pseudomonas aeruginosa infection in cystic fibrosis: nucleotide sequence and transcriptional regulation of the algD gene. Nucleic Acids Res 1987; 15: 4567-4581.

8. Valerius NH, Koch C, Høiby N. Prevention of chronic Pseudomonas aeruginosa colonisation in cystic fibrosis by early treatment. Lancet $1991 ; 338$ : 725-726.

9. Vazquez C, Municio M, Corera M, Gaztelurrutia L, Sojo A, Vitoria JC. Early treatment of Pseudomonas aeruginosa colonization in cystic fibrosis. Acta Paediatr 1993; 82: 308-309.

10. Relman DA. Universal bacterial 16S rRNA amplification and sequencing. In: Persing DH (ed) Diagnostic molecular microbiology: principles and applications. Rochester, MN, Mayo Foundation. 1993: 489-490.

11. Sambrook J, Fritsch EF, Maniatis T. Molecular cloning: a laboratory manual. 2nd edn. Cold Spring Harbor, NY, Cold Spring Harbor Laboratory Press. 1989.

12. Campbell PW, Phillips JA, Heidecker GJ, Krishnamani MRS, Zahorchak R, Stull TL. Detection of Pseudomonas (Burkholderia) cepacia using PCR. Pediatr Pulmonol 1995; 20: 44-49.

13. Holloway BW, Dharmsthiti S, Krishnapillai V et al. Patterns of gene linkages in Pseudomonas species. In: Drlica K, Kiley M (ed) The bacterial chromosome. Washington, DC, American Society for Microbiology. 1990: 97-105.

14. McIntosh I, Govan JRW, Brock DJH. Detection of Pseudomonas aeruginosa in sputum from cystic fibrosis patients by the polymerase chain reaction. Mol Cell Probes 1992; 6: 299-304.

15. O'Callaghan EM, Tanner MS, Boulnois GJ. Development of a PCR probe test for identifying Pseudomonas aeruginosa and Pseudomonas (Burkholderia) cepacia. J Clin Pathol 1994; 47: $222-226$.

16. De Vos D, Lim A, Pirnay J-P et al. Direct detection and identification of Pseudomonas aeruginosa in clinical samples such as skin biopsy specimens and expectorations by multiplex PCR based on two outer membrane lipoprotein genes, oprI and oprL. J Clin Microbiol 1997; 35: 1295-1299.

17. Shak S. Aerosolized recombinant human DNase I for the treatment of cystic fibrosis. Chest 1995; 107 Suppl: 65S-70S. 